\title{
Aichivirus in Children with Diarrhea in Northern Italy
}

\author{
Massimiliano Bergallo ${ }^{a, b} \quad$ llaria Galliano ${ }^{a, b}$ Paola Montanaria, ${ }^{a} \quad$ Marco Rassu $^{a}$ \\ Valentina Dapràa \\ ${ }^{a}$ Department of Public Health and Pediatric Sciences, University of Turin Medical School, Turin, Italy; ${ }^{b}$ SC Pediatric U \\ Regina Margherita Hospital, Turin, Italy
}

\section{Keywords}

Aichivirus A - Real-time polymerase chain reaction .

Gastroenteritis · RNA extraction · Coinfection

\begin{abstract}
Objective: Since its discovery, Aichivirus (AiV) A has been detected, with an incidence of $0.9-4.1 \%$, primarily when studying outbreaks of diarrhea in children or young adults. In this paper, we report the first detection of AiV in Piedmont, Italy, in pediatric patients. Methods: A total of $159 \mathrm{fecal}$ specimens (from 96 males and 63 females) previously screened for rotaviruses, adenoviruses, noroviruses, human parechoviruses, saliviruses, and sapoviruses were collected from infants and children with acute gastroenteritis. Results: The most commonly detected virus was norovirus GII (33.80\%), followed by rotavirus $(21.30 \%)$, astrovirus (18.87\%), bocavirus (13.92\%), sapovirus (10.90\%), parechovirus (8\%), norovirus GI (6.70\%), adenovirus (1\%), and salivirus (0.52\%). Realtime polymerase chain reaction detected AiV A in $1(0.62 \%)$ case subjects. AiV A was detected in monoinfection only in January. Conclusions: Our results indicate that AiV may be associated with a limited number of diarrhea cases in pediatric patients.

(c) 2018 S. Karger AG, Basel
\end{abstract}

๑) 2018 S. Karger AG, Basel

E-Mail karger@karger.com

www.karger.com/int

\section{Introduction}

Gastroenteritis is a common disease in children, characterized by diarrhea, vomiting, abdominal pain, and fever. Pediatric gastroenteritis remains the second most common cause of child mortality worldwide [1]. Diarrheal disease can be caused by a wide spectrum of pathogens (parasites, bacteria, and viruses). In the last decade, there has been a great shift from conventional methods to identify viral pathogens to the utilization of polymerase chain reaction (PCR) assays, which have proven their advantages over previously used techniques such as rapid antigen detection and viral culture [2]. The major benefits of molecular diagnostic methods are lower detection limits and, therefore, a higher analytical sensitivity for common viruses such as rotaviruses (RV) and adenoviruses $(\mathrm{AdV})$, and their ability to detect uncultivable viruses such as noroviruses (NoV), sapoviruses ( $\mathrm{SaV})$, and astroviruses (HAstrV) [3-6]. Moreover, real-time PCR has the ability to determine the viral load in a semiquantitative way, expressed as the amount of amplification cycles (cycle threshold value) necessary to detect the pathogen. There is, however, a large diagnostic gap, resulting in the etiologic agent not being identified in approximately a
Dr. Massimiliano Bergallo, $\mathrm{PhD}$

Department of Public Health and Pediatric Sciences, University of Turin Medical School Piazza Polonia 94

IT-10136 Turin (Italy)

E-Mail massimiliano.bergallo@unito.it 
third of all specimens, and it has been suggested that other viruses, including picornaviruses, are involved [7]. Aichi virus (AiV) was first discovered in 1989 during a search for an infectious agent in an outbreak of oyster associated nonbacterial gastroenteritis [8]. The isolated virus was later classified as the first member of a novel genus, i.e., Kobuvirus, of the family Picornaviridae [9]. Kobuviruses have since then been associated with diarrhea not only in humans but also in cattle $[10,11]$ and swine $[12,13]$. Since its discovery, AiV has been detected with an incidence of $0.9-4.1 \%$, primarily when studying outbreaks of diarrhea in children or young adults [14-18]. $\mathrm{AiV}$ seems to be circulating worldwide, and detection of AiV has been reported in Asia [19], South America [20], Europe [13-15, 20], and Africa [17]. Previous studies have suggested oysters, or other seafood, to be the source of AiV infections [2, 14, 17, 21,22] but its occurrence has also been reported in sewage $[17,23]$, which indicates that kobuviruses might use the fecal-oral route of infection, like several other picornaviruses. Although doubts exist regarding its clinical role because of frequent codetection (50-80\%) of AiV and other viral agents $[14,15,24]$ and low incidence rates $(0.9-4.1 \%)$ in acute gastroenteritis $[15,24-26]$, other studies have recently yielded contrasting results, showing that codetection of $\mathrm{AiV}$ with other common enteropathogenic viruses occurs at a low rate [27] and that this virus is rarely detected in healthy individuals [27-29], which supports a possible role of this virus in gastroenteritis. In this paper, we report the first detection of $\mathrm{AiV}$ in Piedmont, Italy. In addition, this is the first paper describing the presence of AiV in Piedmont pediatric patients.

\section{Materials and Methods}

\section{Target Sequence Selection}

The primers and probe were designed based on alignment of all of the available relevant virus sequences in GenBank (http:// www.ncbi.nlm.nih.gov/genbank/) in July 2010 using ClustalW (http://www.clustal.org/) and Primer3 software (http://frodo.wi. mit.edu/primer $3 /$ ). The primers and probe target a highly conserved part of the $5^{\prime}$ untranslated region [26]. The primers for internal control, i.e., glyceraldehyde-3-phosphate dehydrogenase (GAPDH), have been previously published [30].

\section{Fecal Specimens}

A total of 159 fecal specimens (from 96 males and 63 females) previously screened for NoV, RV, and AdV (192 samples), human parechovirus ( $\mathrm{HPeV}$ ) and $\mathrm{SaV}$ (137 samples), and SalV, HAstrV, and human bocavirus (HBoV) (123 samples) were collected from infants and children with acute gastroenteritis in the Pediatric Hospital Regina Margherita (Turin in Italy) from December 2014 to November 2015 and tested for human AiV. This study was performed according to the guidelines of the institutional review board on the use of biologic specimens for scientific purpose in keeping with Italian law (art. 13 D.Lgs 196/2003). The samples were collected from children under the age of 5 years with acute gastroenteritis in the Pediatric Hospital Regina Margherita from December 2014 to April 2015. Acute gastroenteritis was defined as the rapid onset of 2 or more of the following symptoms: diarrhea, vomiting, nausea, fever, and abdominal pain. Patients who met any of the following criteria were not eligible for this study: immunosuppressive therapy and age $>5$ years. This study was approved by our institutional ethics committee on November 24, 2014 (protocol No. 116918).

\section{Nucleic Acid Extraction}

A total of $50 \mu \mathrm{g}$ of fecal specimens (previously diluted 1/10 in $0.9 \% \mathrm{NaCl}$ buffer saline solution) were extracted on a Maxwell automated extractor (Promega, Madison, WI, USA) using the RNA Blood Kit protocol without modifications. Samples were eluted in $50 \mu \mathrm{L}$ of distilled water.

\section{Reverse Transcription}

For reverse transcription (RT), $5 \mu \mathrm{L}$ of the stored, extracted RNA was added to a reagent mixture consisting of $5 \times$ first-strand buffer (Applied Biosystems, Carlsbad, CA, USA), $10 \mathrm{mM}$ dNTP (Sigma, St. Louis, MO, USA ), MuLV (50 U/ $\mu \mathrm{L}$ ) (Applied Biosystems), a random primer $(50 \mu \mathrm{M}$, hexa-deoxyribonucleotide mixture; Promega), RNase inhibitor $(40 \mathrm{U} / \mu \mathrm{L})$ (Promega), and distilled water. The total volume of the reaction mixture was $50 \mu \mathrm{L}$. The RT reaction was carried out at $42^{\circ} \mathrm{C}$ for $15 \mathrm{~min}$, followed by $99^{\circ} \mathrm{C}$ for $5 \mathrm{~min}$ and then $5^{\circ} \mathrm{C}$ for $5 \mathrm{~min}$ [30].

\section{Real-Time PCR}

Optimization of the PCR reaction was performed by determining the optimal amount of primers and probe, as well as the cycling conditions. The optimized AiV PCR reaction contained $5 \mu \mathrm{L}$ of extracted DNA, $200 \mathrm{nM}$ of AiV primer forward, $900 \mathrm{nM}$ of AiV primer reverse, $200 \mathrm{nM}$ of the AiV FAMprobe, and $1 \times$ PCR Master Mix (Applied Biosystems) in a total of $20 \mu \mathrm{L}$ of reaction. The PCR amplification was carried out for $2 \mathrm{~min}$ at $50^{\circ} \mathrm{C}, 10 \mathrm{~min}$ at $95^{\circ} \mathrm{C}$, 45 cycles of $15 \mathrm{~s}$ at $95^{\circ} \mathrm{C}$, and $1 \mathrm{~min}$ at $60^{\circ} \mathrm{C}$ on a $7500 \mathrm{ABI}$ realtime instrument (Applied Biosystems).

\section{Internal Control}

AiV and GAPDH PCR amplification were performed in singleplex reactions to evaluate the potential interference between PCR targets. A negative AiV result was considered valid only if the internal control GAPDH probe showed amplification.

\section{Gastroenteric Virus Detection}

The following information was extracted from the medical record database: age, gender, RV and AdV. HPeV, SaV, NoV, SalV, $\mathrm{HAstrV}$, and $\mathrm{HBoV}$ were detected as previously reported [31-33].

Specificity

The analytical specificity of the RT PCR assay was determined by testing coxsackievirus B1 (ATCC VR-28), B2 (ATCC VR-29), and B3 (ATCC VR-30), enterovirus type 68 (ATCC VR-561), 69 (ATCC VR-785), 70 (ATCC VR-836), and 71 (ATCC VR-1432), human orthopneumovirus (ATCC VR-26), influenza viruses (influenza A virus H1N1 [ATCC VR-95], H3N2 [ATCC VR-547], and influenza B virus [ATCC VR-101]), herpes simplex virus 1 (ATCC VR-260), human betaherpesvirus 5 (ATCC VR-538), hu- 
Fig. 1. Monthly distribution of the major viral pathogens in pediatric patients with gastroenteritis.

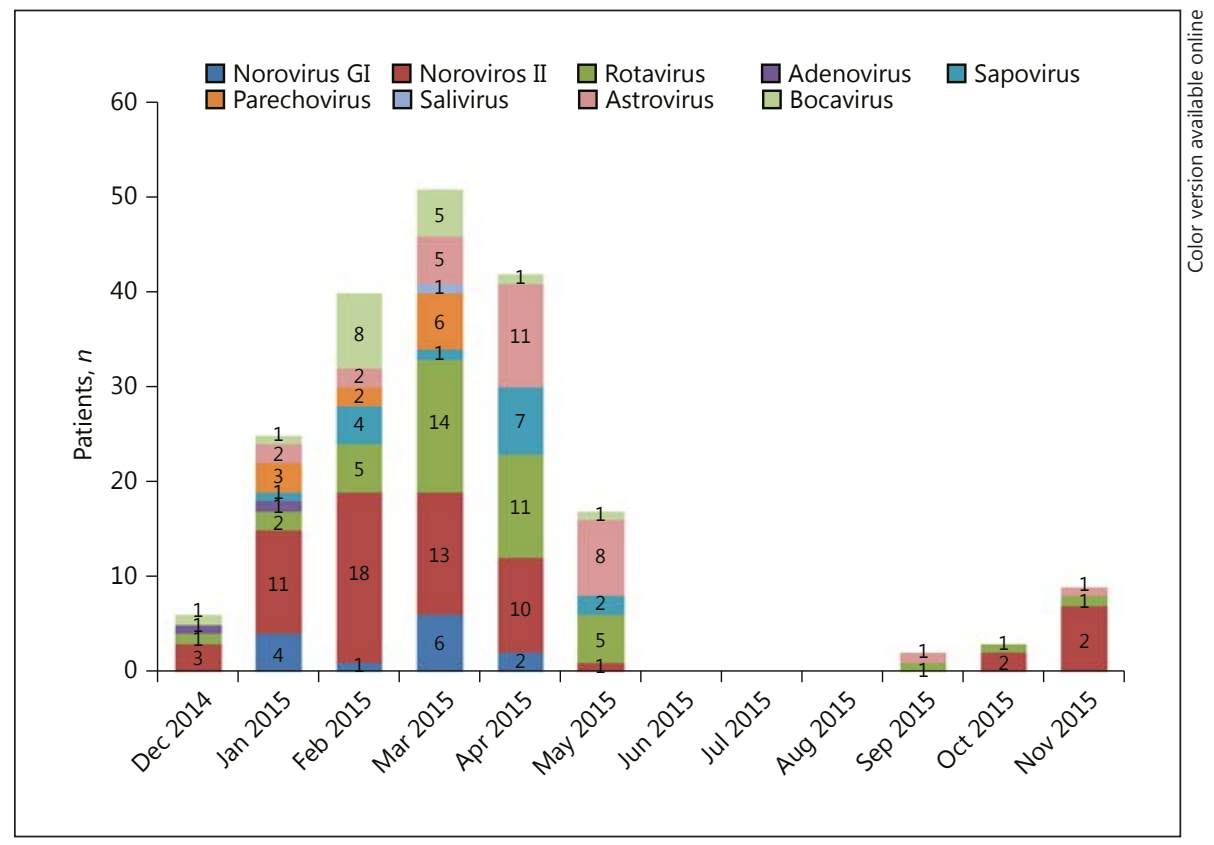

Table 1. Detected enteric viruses: coinfection data

\begin{tabular}{lcc}
\hline Viral pathogen & Infected stools & Coinfection \\
\hline Norovirus GI & $13 / 192$ & $7 / 13(53.8)$ \\
Norovirus GII & $65 / 192$ & $30 / 65(46.1)$ \\
Rotavirus & $41 / 192$ & $19 / 41(46.3)$ \\
Adenovirus & $2 / 192$ & $1 / 2(50)$ \\
Parechovirus & $11 / 137$ & $10 / 11(90.9)$ \\
Sapovirus & $15 / 137$ & $10 / 15(66.6)$ \\
Bocavirus & $17 / 123$ & $13 / 17(76.47)$ \\
\hline
\end{tabular}

Values are presented as numbers/total or numbers/total (\%).

man gammaherpesvirus 4 (ATCC VR-602), human coronavirus types 229E (ATCC VR-740) and OC43 (ATCC VR-1558), Escherichia coli (ATCC 25922), Legionella pneumophila (ATCC 33152), Enterococcus faecalis (ATCC 29212), Bacillus cereus (ATCC 14579), Haemophilus influenzae (ATCC 49766), Staphylococcus aureus (ATCC 25923), and Lactobacillus plantarum (ATCC 8014).

\section{Results}

\section{Common Viral Agents in Children}

The mean age of the tested patients was $21.6 \pm 10.3$ months. The majority of the children (86\%) were 1-36 months of age. The most commonly detected virus was NoV GII (33.80\%), followed by RV (21.30\%), HAstrV
(18.87\%), HBoV (13.92\%), SaV (10.90\%), HPeV (8\%), NoV GI (6.70\%), AdV (1\%), and SalV (0.52\%). The monthly distribution of the viral pathogens is described in Figure 1, which suggests that gastrointestinal virus detection peaked during the Italian winters; however, since the number of tested stools was rather limited, a larger sampling will be required to confirm any seasonality pattern. Multiple infections with 1-4 viruses responsible for gastroenteritis in humans stool were found (Table 1).

\section{Detection of $\mathrm{AiV}$}

Real-time PCR detected AiV in 1 (0.62\%) subject. The virus was detected in a viral monoinfection in January.

\section{Discussion}

Currently, RT PCR is used widely and considered to be a convenient, useful, and powerful method for molecular diagnosis to detect pathogens from clinical specimens. With the development of real-time PCR assays, many of the limitations related to performing PCR amplification in a clinical laboratory have been overcome. In the present study, stool specimens $(n=159)$ obtained from Italian children aged $<5$ years who presented with acute diarrhea were retrospectively analyzed for AiV using RT real-time PCR. The stool specimens were collected from 2014 to 2015 in the city of Turin (Italy). Since its 
discovery, AiV has been detected with an incidence of $0.9-4.1 \%$, primarily when studying outbreaks of diarrhea in children or young adults [14-18]. Our results confirmed that enteric viruses play an important role in pediatric diarrhea, and further that the most common viral agent associated with gastroenteritis is $\mathrm{NoV}$, followed by RV, HAstrV, HBoV, SaV, HPeV, AdV, and SalV. The prevalence rates of $\mathrm{RV}, \mathrm{SaV}, \mathrm{HPeV}, \mathrm{AdV}$, and $\mathrm{HBoV}$ were similar to those reported previously [32, 34-36]. However, the detection rates of 40.5 and $18.87 \%$ for NoV and HAstrV, respectively, in this study were higher than those reported previously in Italy [37-39] but similar to those in the recent study of Rovida et al. [40]. Moreover, RV detection peaked during spring, which is in conflict with the results of previous studies [41].

AiV has been associated with gastroenteritis in children and young adults in Germany [20], France [14], Hungary [13], Tunisia [17], Pakistan [18], China [27], and Finland [15]. Our data showed that the detection rate of $\mathrm{AiV}$ in diarrheal children $(0.62 \%)$ was similar to those observed in other countries [15, 26, 42-45]. A limitation of our study is the small number of stool samples from gastroenteritis and the lack of samples from healthy controls. In conclusion, the present study investigated the presence of $\mathrm{AiV}$ in pediatric patients with diarrhea in Piedmont, Italy. Our results indicate that AiV may be associated with a limited number of diarrhea cases even in elderly pediatric patients. The discrepancies between the high seroprevalence and the low incidence of detection could be due to AiV infections being mainly asymptomatic. Seroprevalence studies have shown that $80-95 \%$ of the population in their 30 s has antibodies against $\mathrm{AiV}[20$, $46,47]$, which indicates a general and frequent circulation of the virus among humans. The reported incidence of $\mathrm{AiV}$ is in general low, but it is significantly higher in outbreaks of gastroenteritis associated with shellfish $[14,17]$. However, the high seroprevalence, even in the very young population, indicates the possibility of other transmission routes. AiV has recently been detected in sewage and sewage-polluted water in Venezuela [23] and Tunisia [17], which indicates a circulation of $\mathrm{AiV}$ in the environment. Given the low prevalence of $\mathrm{AiV}$ in our population, the $\mathrm{AiV}$ result will require confirmation using a much larger sample size from healthy individuals. AiV remains rare, and the significance of $\mathrm{AiV}$ as a human pathogen is a question that remains to be further investigated.

\section{Acknowledgment}

This study was supported by an institutional grant to Bergallo (ex60\% 2015).

\section{Disclosure Statement}

The authors have no conflict of interests to declare.

\section{References}

1 Black RE, Cousens S, Johnson HL, Lawn JE, Rudan I, Bassani DG, Jha P, Campbell H, Walker CF, Cibulskis R, Eisele T, Liu L, Mathers C; Child Health Epidemiology Reference Group of the WHO and UNICEF: Global, regional, and national causes of child mortality in 2008: a systematic analysis. Lancet 2010;375:1969-1987.

-2 Amar CF, East CL, Gray J, et al: Detection by PCR of eight groups of enteric pathogens in 4,627 faecal samples: re-examination of the English case-control Infectious Intestinal Disease Study (1993-1996). Eur J Clin Microbiol Infect Dis 2007;26:311-323.

-3 Simpson R, Aliyu S, Iturriza-Gómara M, et al: Infantile viral gastroenteritis: on the way to closing the diagnostic gap. J Med Virol 2003; $70: 258-262$.

4 Logan C, O’Leary JJ, O’Sullivan N: Real-time reverse transcription-PCR for detection of rotavirus and adenovirus as causative agents of acute viral gastroenteritis in children. J Clin Microbiol 2006;44:3189-3195.
5 van Maarseveen NM, Wessels E, de Brouwer CS, et al: Diagnosis of viral gastroenteritis by simultaneous detection of adenovirus group F, astrovirus, rotavirus group A, norovirus genogroups I and II, and sapovirus in two internally controlled multiplex realtime PCR assays. J Clin Virol 2010;49:205210.

-6 Wolffs PF, Bruggeman CA, van Well GT, et al: Replacing traditional diagnostics of fecal viral pathogens by a comprehensive panel of real-time PCRs. J Clin Microbiol 2011;49: 1926-1931.

7 Glass RI, Bresee J, Jiang B, et al: Gastroenteritis viruses: an overview. Novartis Found Symp 2011;238:5-19.

8 Yamashita T, Kobayashi S, Sakae K, et al: Isolation of cytopathic small round viruses with BS-C-1 cells from patients with gastroenteritis. J Infect Dis 1991;164:954-957.

-9 Yamashita T, Sakae K, Tsuzuki H, et al: Complete nucleotide sequence and genetic organization of Aichi virus, a distinct member of the
Picornaviridae associated with acute gastroenteritis in humans. J Virol 1998;72:84088412.

10 Yamashita T, Ito M, Kabashima Y, et al: Isolation and characterization of a new species of kobuvirus associated with cattle. J Gen Virol 2003;84:3069-3077.

11 Reuter G, Egyed L: Bovine kobuvirus in Europe. Emerg Infect Dis 2009;15:822-823.

$\checkmark 12$ Reuter G, Boldizsar A, Kiss I, et al: Candidate new species of Kobuvirus in porcine hosts. Emerg Infect Dis 2008;14:1968-1970.

13 Reuter G, Boldizsar A, Pankovics P: Complete nucleotide and amino acid sequences and genetic organization of porcine kobuvirus, a member of a new species in the genus Kobuvirus, family Picornaviridae. Arch Virol 2009; 154:101-108

14 Ambert-Bakay K, Lorrot M, Bon F, et al: Prevalence and genetic diversity of Aichi virus strains in stool samples from community and hospitalized patients. J Clin Microbiol 2008; 46:1252-1258. 
15 Kaikkonen S, Rasanen S, Ramet M, et al: Aichi virus infection in children with acute gastroenteritis in Finland. Epidemiol Infect 2010; 138:1166-1171.

16 Reuter G, Boldizsar A, Papp G, et al: Detection of Aichi virus shedding in a child with enteric and extraintestinal symptoms in Hungary. Arch Virol 2009;154:1529-1532.

17 Sdiri-Loulizi K, Hassine M, Aouni Z, et al: First molecular detection of Aichi virus in sewage and shellfish samples in the Monastir region of Tunisia. Arch Virol 2010;155:15091513.

18 Yamashita T, Sakae K, Kobayashi S, et al: Isolation of cytopathic small round virus (Aichi virus) from Pakistani children and Japanese travelers from Southeast Asia. Microbiol Immunol 1995;39:433-435.

19 Pham NT, Khamrin P, Nguyen TA, et al: Isolation and molecular characterization of Aichi viruses from fecal specimens collected in Japan, Bangladesh, Thailand, and Vietnam. J Clin Microbiol 2007;45:2287-2288.

20 Oh DY, Silva PA, Hauroeder B, et al: Molecular characterization of the first Aichi viruses isolated in Europe and in South America. Arch Virol 2006;151:1199-1206.

21 Le Guyader FS, Le Saux JC, Ambert-Balay K, et al: Aichi virus, norovirus, astrovirus, enterovirus, and rotavirus involved in clinical cases from a French oysterrelated gastroenteritis outbreak. J Clin Microbiol 2008;46: 4011-4017.

22 Hansman GS, Oka T, Li TC, et al: Detection of human enteric viruses in Japanese clams. J Food Prot 2008;71:1689-1695.

23 Alcala A, Vizzi E, Rodriguez-Diaz J, et al: Molecular detection and characterization of Aichi viruses in sewage-polluted waters of Venezuela. Appl Environ Microbiol 2010;76: 4113-4115.

24 Rasanen S, Lappalainen S, Kaikkonen S, et al: Mixed viral infections causing acute gastroenteritis in children in a waterborne outbreak. Epidemiol Infection 2010;138:1227-1234.

25 Jonsson N, Wahlstrom K, Svensson L, et al: Aichivirus infection in elderly people in Sweden. Arch Virol 2012;157:1365-1369.
26 Nielsen AC, Gyhrs ML, Nielsen LP, et al: Gastroenteritis and the novel picornaviruses aichivirus, coasavirus, saffoldvirus, and salivirus in young children. J Clin Virol 2013;57: 239-242.

27 Yang S, Zhang W, Shen Q, et al: Aichi virus strains in children with gastroenteritis, China. Emerg Infect Dis 2009;15:1703-1705.

28 Chhabra P, Payne DC, Szilagyi PG, et al: Etiology of viral gastroenteritis infection in children 5 years of age in the United States, 20082009. J Infect Dis 2013;208:790-800.

29 Drexler JF, Baumgarte S, Luna LK, et al: Aichi virus shedding in high concentrations in patients with acute diarrhea. Emerg Infect Dis 2011;17:1544-1547.

30 Bergallo M, Galliano I, Montanari P, et al: CMV induces HERV-K and HERV-W expression in kidney transplant recipients. J Clin Virol 2015;68:28-31.

-31 Pang X, Lee BE: Laboratory diagnosis of noroviruses: present and future. Clin Lab Med 2015;35:345-362.

32 Bergallo M, Galliano I, Montanari P, et al: Molecular detection of human parechovirus in under-five-year-old children with gastroenteritis. J Clin Virol 2016;85:17-21.

33 Bergallo M, Galliano I, Montanari P, et al: Development of a quantitative real-time PCR assay for sapovirus in children under 5-yearsold in Regina Margherita Hospital of Turin, Italy. Can J Microbiol 2017;63:296-302.

34 Raymaekers M, Smets R, Maes B, et al: Checklist for optimization and validation of realtime PCR assays. J Clin Lab 2009;23:145-151.

- 35 Levican J, Navas E, Orizola J, et al: Human bocavirus in children with acute gastroenteritis, Chile, 1985-2010. Emerg Infect Dis 2013; 19:1877-1880.

36 Alam MM, Khurshid A, Shaukat S, et al: Human bocavirus in Pakistani children with gastroenteritis. J Med Virol 2015;87:656-663.

37 Rovida F, Campanini G, Piralla A, et al: Molecular detection of gastrointestinal viral infections in hospitalized patients. Diagn Microbiol Infect Dis 2013;77:231-235.
38 Medici MC, Tummolo F, Albonetti V, Abelli LA, Chezzi C, Calderaro A: Molecular detection and epidemiology of astrovirus, bocavirus, and sapovirus in Italian children admitted to hospital with acute gastroenteritis, 2008-2009. J Med Virol 2012;84:643-650.

39 Rimoldi SG, Stefani F, Pagani C, Chenal LL, Zanchetta N, Di Bartolo I, Lombardi A, Ruggeri FM, Di Lillo D, Zuccotti GV, Gismondo MR: Epidemiological and clinical characteristics of pediatric gastroenteritis associated with new viral agents. Arch Virol 2011;156: 1583-1589.

40 Rovida F, Premoli M, Campanini G, Sarasini A, Baldanti F: Evaluation of Xpert ${ }^{\circledR}$ Norovirus Assay performance in comparison with real-time RT-PCR in hospitalized adult patients with acute gastroenteritis. Diagn Microbiol Infect Dis 2016;85:426-427.

-41 Marchetti F, Vetter V, Conforti G, Esposito S, Bonanni P: Parents' insights after pediatric hospitalization due to rotavirus gastroenteritis in Italy. Hum Vaccin Immunother 2017; 13:2155-2159.

42 Verma H, Chitambar SD, Gopalkrishna V: Circulation of Aichi virus genotype B strains in children with acute gastroenteritis in India. Epidemiol Infect 2011;139:1687-1691.

43 Han TH, Park SH, Hwang ES, et al: Detection of Aichi virus in South Korea. Arch Virol 2014;159:1835-1839.

-44 Thongprachum A, Takanashi S, Kalesaran AF, et al: Four-year study of viruses that cause diarrhea in Japanese pediatric outpatients. J Med Virol 2015;87:1141-1148.

45 Chuchaona W, Khamrin P, Yodmeeklin A, et al: Detection and characterization of Aichi virus 1 in pediatric patients with diarrhea in Thailand. J Med Virol 2017;89:234-238.

46 Goyer M, Aho LS, Bour JB, Ambert-Balay K, Pothier P: Seroprevalence distribution of Aichi virus among a French population in 2006-2007. Arch Virol 2008;153:1171-1174.

47 Ribes JM, Montava R, Tellez-Castillo CJ, Fernandez-Jimenez M, Buesa J: Seroprevalence of Aichi virus in a Spanish population from 2007 to 2007. Clin Vaccine Immunol 2010;17: 545-549.
AiV in Children with Diarrhea in Northern Italy 